\title{
Prevalence of common bacterial pathogens in marine fishes
}

\author{
Elsayed, M.E ${ }^{*}$; Essawy, A.M**; Abou El-Atta, M.E ${ }^{* * * *}$ and EL- \\ Banna,N.I ${ }^{* * * * *}$. \\ *Professor of Microbiology, Faculty of Veterinary Medicine, Suez Canal \\ University. \\ **Head Research of Microbiology, Animal Health Research Institute. \\ ***Senior Research, Fish health dept. Central laboratory for Aquaculture, \\ Research. \\ ****Researcher of Microbiology, Animal Health Research Institute.
}

\begin{abstract}
:
A total of 200 marine fish of two different species represented as (100 Tilapia zillii\&100 Mugi Capito) were freshly collected randomly from different markets in EL-Mansoura city, during different seasons. And subjected to clinical, post mortem and bacteriological studies .The common clinical signs were darkness in skin, hemorrhage in base of fins, eyes \&different parts on the body, and abdominal distention, congestion in gills and increase in mucous secretion. The Post Mortem finding showed white serous fluid in abdominal cavity and sometime tinged with blood, pale or congested liver, kidney and spleen. The result indicated that the prevalence of bacterial pathogens among naturally infected marine fish were A. hydrophila 52 isolates (39.39\%), V.alginolyticus 38 isolates(28.79\%), Ps.fluorescens 24isolate s $(18.18 \%), \boldsymbol{V}$. cholerae 10 isolates (7.58\%) and Ps.aeruginosa8 isolates (6.06\%). And among the seasons the highest prevalence of bacterial infection recorded in summer season $(33.33 \%)$ followed by spring (24.42\%), then autumn (21.97\%), while minimal prevalence recorded in winter season $(20.46 \%)$. The results of pathogenicity declared that the A. hydrophila was highly pathogenic to T.zillii causing $100 \%$ mortality within 4 days followed by V.alginolyticus causing (90\%) mortality, then Ps. Fluorescens(80\%), Ps.aeruginosa(60\%)while $V$. cholerae was non pathogenic strain .The results of antibiogram revealed that, ciprofloxacin and naladixic acid were more effective against $A$.hydrophila, while ciprofloxacin and rifampicine more effective against $P$ s. fluorescens also ciprofloxacin and amikacine against Ps.aeruginosa. While V.alginolyticus was highly sensitive to ciprofloxacin.
\end{abstract}

Keywords: Marine fish, Bacterial diseases, Isolation, Seasonal variation, Antibiotic sensitivity. 


\section{Introduction}

Aquaculture is considered an important source of high nutritive value, cheap animal proteins and it becomes an important economic activity in many countries. In this way the Egyptian Government within the strategy of the food, paid special interest to fish meat and within this strategy fish aquaculture and fish industry were considered as one of the main principal sources of the national income in Egypt .On the long run water resources will be the most limiting factor to be considered in aquaculture development in Egypt, especially freshwater aquaculture. Therefore, marine water is the immediate alternative sources for water needed for mariculture system.

According to Toranzo et al (2005) several aspects would be raised regarding the infectious diseases caused by bacteria in marine fish: (i) Only a relatively small number of pathogenic bacteria are responsible for important and significant economic losses in cultured fish;

(ii) Several classical diseases considered as typical of fresh water aquaculture are today important problems in marine culture;

(iii) Clinical signs (external and internal) provoked by each pathogen depend on the host species, fish age and stage of the disease; (iv) There is no correlation between external and internal signs of the disease; and (v) The severity of the disease and the mortality are higher in cultured fish than that in wild fish populations, due to the lack of the stressful conditions that usually occur in the culture facilities.

The present work was planned to isolate and identify the most common pathogenic bacteria in some marine fish and evaluate the seasonal variation, prevalence in different organs of isolated bacteria and antibiotic sensitivity of pathogenic one among examined fish.

\section{Material and methods \\ 2.1. Sampling:}

A total of 200 marine fish of two different spp. represented as (100 T.zillii and 100 M.Capito ) were freshly collected randomly from different markets in EL-Mansoura city, during different seasons .In a rate 25 fish of each species were collected and examined seasonally. Clinical and P.M examination were carried out using the methods described by (Schäperclaus et al, 1992).

\subsection{Isolation of suspected bacteria:}

Samples from liver, kidney, spleen and gills from examined fish were cultured on general and selective media; tryptic soy broth, tryptic soy agar (oxoid) supplemented with $2 \%$ $\mathrm{NaCl}(\mathrm{w} / \mathrm{v})$, thiosulphate citrate bile salt agar (oxoid), aeromonas base media supplemented with ampicillin and pseudomonas agar base media supplemented with $2 \% \mathrm{NaCl}(\mathrm{w} / \mathrm{v})$ and glycerin $2 \%$. All inoculated 
media were incubated at $28^{\circ} \mathrm{c}$ for $1-$ 2 days.

\subsection{Identification of isolated bacteria:}

Pure cultures of isolated bacteria were identified by gram stain and biochemically as described in the (Bergey's manual of systemic bacteriology, 2005). Final confirmation of bacterial isolates was achieved by using the analytical profile index of API20 E system (Buller, 2004).

\subsection{Experimental infection:}

A total number of 70 T.zillii fish were collected alive and apparently healthy from EL Abbassa fish farm, EL sharkia, Egypt with an average body weight $20 \pm 5 \mathrm{~g}$ and were used for experimental infection with $A$. hydrophila, Ps.fluorescens, Ps.aeruginosa, V.alginolyticus and V.cholerae isolated from naturally infected marine fish. The Fish were maintained in glass aquaria supplied with well aerated dechlorinated tap water with addition of salt to be acclimated. All experimental fish were feed with commercial ration at rate of $5 \%$ body weight per day.

Fish were divided into seven groups (10 fish of each) and the inocula of bacterial isolates were prepared for $\mathrm{I} / \mathrm{P}$ injections, according to (Austin \& Austin, 1999). Five groups were consistently inoculated I/P with bacterial suspension of (Aeromonas hydrophila, Ps. fluorescence, Ps.aeruginosa, V.alginolyticus and $V$. cholerae) at dose of $0.2 \mathrm{ml}$ of (3 $\begin{array}{llll}\mathrm{X} & 10^{7} & \mathrm{CFU}) & \text { using }\end{array}$ spectrophotometer to adjust dose.
The sixth group were injected I/P with $0.2 \mathrm{ml}$ of saline containing $V$. cholerae $\left(2.5 \times 10^{8} \mathrm{CFU} / \mathrm{ml}\right)$ (Austin and Austin, 2007). The last group was left as control and injected I/P with $0.2 \mathrm{ml}$ sterile saline. As shown in (Table 5). All experimentally injected fish observed daily for 1-2 weeks to record any clinical signs and mortalities. Postmortem examination was done on freshly dead fish to record gross lesions. And re-isolation of injected pathogenic bacteria from dead and scarified fish.

\subsection{Antibiogrom sensitivity:}

Were done according to Schaperclaus et al (1992), using the disc diffusion method on Muller's Hinton agar medium and following discs oxytetracycline, ampicillin, amoxycillin, lincomycin, Ciprofloxacin,

colistinsulphate,nalidixic acid, amikacin, rifampcine and erythromycin, that were kindly recorded.

\section{Result}

\subsection{Results of Clinical and P.M examination:}

Symptoms detected in the naturally diseased fish included darkness of external body surface, opacity of eye, increased in mucous secretion, exophthalmia and some fish showed hemorrhages in eye, and large irregular hemorrhagic areas into many parts of the body, at base of fins, on gills cover, at the anal region, anal fin .There were abdominal distention observed in 
some fish. The Post mortem examination showed white serous fluid in abdominal cavity, some tinged with blood. The liver appeared pale anemic, friable with some hemorrhagic patches and pinpoint hemorrhagic on liver surface. Kidney were congested and slightly enlarged .The intestine of some fish were hemorrhagic, inflamed with sever congestion. Spleen enlarged and congested and in some cases appeared pale and in other cases appeared normal. In some fish appear hemorrhagic areas in the abdominal wall \&on peritoneum. (Photo1).

\subsection{Results of bacteriological examination:}

The results of bacteriological examination of examined fish revealed the isolation of 132 bacterial isolates of gram negative bacteria which identified according to morphological, biochemical and API20 into A.hydrophila, Ps. fluorescens, Ps.aeruginosa, V.alginolyticus and $V$. cholerae as shown in (Table 1). The result indicated that 99 naturally infected and 101 apparently healthy marine fish were found to be infected with different types of bacteria. The results shown that from total number of collected gram negative bacterial isolates were 22(14.29\% ) isolates oxidase $-\mathrm{ve}$ and 132(85.71\%) were oxidase positive isolates. From oxidase positive bacterial isolates the higher percentage was recorded to A.hydrophila 52(39.39\%), followed by V.alginolyticus $38(28.79 \%)$, Ps. fluorescens 24 (18.18\%) and the minimal prevalence was recorded for $V$. cholerae $10(7.58 \%)$ and Ps.aeruginosa8 (6.06\%). (Table 2).

The highest prevalence of bacterial pathogens among the naturally infected marine fish was recorded in the summer season (33.33\%), followed by the spring (24.24\%), then autumn $(21.97 \%)$, in contrast the minimal prevalence of infection recorded in winter(20.46\%) (Table 3 ). The distribution of different bacterial isolates in different organs and tissues of examined marine fish as shown in (Table 4). The highest rate of $A$. hydrophila isolation was recorded in liver $(44.23 \%)$, while the minimal prevalence recorded in gills (7.69\%). Ps.fluorescens was isolated in high percentage from kidney (50\%), followed by liver (25\%), and lowest percentage was recorded from spleen $(8.33 \%)$. The highest prevalence of $P$ s.aeruginosa was recorded in liver and kidney with the same percent $(37.5 \%)$ and the minimal prevalence was recorded also equally in spleen and gills (12.5\%).V.alginolyticus was recorded in higher rate in liver $(36.84 \%)$, while the lower rate recorded in gills $(7.89 \%)$. The highest prevalence of $V$. cholerae was recorded in kidney (40\%), while the lowest prevalence was recorded in gills (10\%).

\subsection{Result of experimental infection:}

Result of pathogenicity test (Table 5) showed that clinical signs of the 
disease were seen after $24 \mathrm{hrs}$ post injection of fish with different pathogenic bacterial isolates (A.hydrophila , Ps.fluorescens, Ps.aeruginosa and V.alginolyticus) and this signs included inflammatory changes at site of injection, hemorrhages all over the body, bilateral distention of abdomen, congested liver, kidney and spleen. Re-isolation of the pathogenic bacterial isolates were obtained from all freshly dead and scarified experimentally infected fish. Mortality rate recorded for pathogenic bacteria was $(100 \%$, $80 \%, 60 \%$ and $90 \%)$ respectively.
While the I/P infected fish groups with $V$. cholerae of two concentration showed no clinical signs or no mortalities which proved that these strains were non pathogenic.The results of antibiogram revealed that, ciprofloxacin and naladixic acid were more effective against $A$ .hydrophila, while ciprofloxacin and rifampicine more effective against Ps. fluorescens also ciprofloxacin and amikacine against Ps.aeruginosa .While V.alginolyticus was highly sensitive to ciprofloxacin.

Table (1): The biochemical and morphological characters of isolated bacteria from examined marine fish.

\begin{tabular}{|c|c|c|c|c|c|}
\hline & $\begin{array}{c}\text { A. } \\
\text { hydrophila. }\end{array}$ & $\begin{array}{c}\text { Ps. } \\
\text { fluorescens. }\end{array}$ & $\begin{array}{c}\text { Ps. } \\
\text { aeruginosa. }\end{array}$ & $\begin{array}{c}V . \\
\text { alginolyticus. }\end{array}$ & $\begin{array}{c}\text { V. } \\
\text { Cholerae. }\end{array}$ \\
\hline 1. Gram stain. & - & - & - & - & - \\
\hline 1. Shape. & Short rod. & Short rod & Short rod & $\begin{array}{l}\text { vebrionic } \\
\text { bacilli }\end{array}$ & $\begin{array}{c}\text { vebrionic } \\
\text { bacilli }\end{array}$ \\
\hline 2. $\quad$ Motility. & + & + & + & + & + \\
\hline 3. $\quad$ Cytochrome oxidase. (Ox). & + & + & + & + & + \\
\hline 4. $\quad$ Catalase Test. & + & + & + & + & + \\
\hline $\begin{array}{l}\text { 5. B-Galactosidase production } \\
\text { (OPNG). }\end{array}$ & + & - & - & - & + \\
\hline $\begin{array}{l}\text { 6. Arginine dihydrolase } \\
\text { production (ADH) }\end{array}$ & - & + & + & - & - \\
\hline $\begin{array}{l}\text { 7. Lysine decarboxylase } \\
\text { production (LDC) . }\end{array}$ & - & + & - & + & - \\
\hline $\begin{array}{l}\text { 8. Ornithine decarboxylase } \\
\text { production (ODC). }\end{array}$ & + & + & - & + & + \\
\hline 9. $\quad$ Citrate utilization (CIT) & - & + & + & - & - \\
\hline 10. $\quad \mathrm{H}_{2} \mathrm{~S}$ production $\left(\mathrm{H}_{2} \mathrm{~S}\right)$. & - & - & - & - & - \\
\hline 11. Urease production (URE). & - & - & + & - & - \\
\hline $\begin{array}{l}\text { 12. Tryptophan deaminase } \\
\text { production (TDA). }\end{array}$ & - & - & - & - & - \\
\hline 13. Indole production (IND). & + & - & - & + & + \\
\hline 14. Acetoin production (VP). & - & - & + & - & + \\
\hline 15. Gelatinase production (GEL). & + & - & + & + & + \\
\hline 16. Acid from glucose & + & - & - & + & $\mathbf{v}$ \\
\hline 17. Acid from manitole. & + & - & - & + & + \\
\hline 18. Acid from inositol. & + & - & - & - & - \\
\hline 19. Acid from sorbitol & + & - & - & - & - \\
\hline 20. Acid from rhaminos. & - & - & - & - & - \\
\hline 21. Acid from sacrose & + & - & - & + & + \\
\hline 22. Acid from melobiose & - & - & - & - & - \\
\hline 23. Acid from amylase & + & - & - & - & - \\
\hline
\end{tabular}


Table (2) Prevalence of $G$-ve, oxidase positive bacterial isolates from examined marine fish.

\begin{tabular}{|c|c|c|c|c|c|}
\hline $\begin{array}{c}\text { No.of } \\
\text { oxidase +ve }\end{array}$ & $\begin{array}{c}\text { A. } \\
\text { hydrophila }\end{array}$ & $\begin{array}{c}\text { Ps. } \\
\text { fluorescens }\end{array}$ & Ps.aeruginosa & V.alginolyticus & $\begin{array}{c}\text { V. } \\
\text { cholerae }\end{array}$ \\
\hline $\mathbf{1 3 2}$ & 52 & 24 & 8 & 38 & 10 \\
\hline $\mathbf{8 5 . 7 1}$ & 39.39 & 18.18 & 6.06 & 28.79 & 7.58 \\
\hline
\end{tabular}

Table (3) Seasonal prevalence of G-ve bacterial species in examined marine fish.

\begin{tabular}{|l|c|c|c|c|c|c|c|c|c|c|}
\hline \multicolumn{1}{|c|}{ Season. } & \multicolumn{2}{c|}{ Winter } & \multicolumn{2}{c|}{ Spring } & \multicolumn{2}{c|}{ Summer } & \multicolumn{2}{c|}{ Autumn } & \multicolumn{2}{c|}{ Total } \\
\cline { 2 - 12 } $\begin{array}{l}\text { Bacterial } \\
\text { Isolates. }\end{array}$ & No. & $\%$ & No. & $\%$ & No. & $\%$ & No. & $\%$ & No. & $\%$ \\
\hline A. hydrophila & 14 & 51.85 & 12 & 37.5 & 18 & 40.91 & 8 & 27.59 & 52 & 39.39 \\
\hline Ps.fluorescens & 8 & 29.63 & 8 & 25 & 0 & 0 & 8 & 27.59 & 24 & 18.18 \\
\hline Ps.aeruginosa & 0 & 0 & 4 & 12.5 & 4 & 9.090 & 0 & 0 & 8 & 6.06 \\
\hline V.alginolyticus & 5 & 18.52 & 7 & 21.88 & 16 & 36.36 & 10 & 34.48 & 38 & 28.79 \\
\hline V. cholerae & 0 & 0 & 1 & 3.13 & 6 & 13.64 & 3 & 10.35 & 10 & 7.59 \\
\hline \multicolumn{1}{|c|}{ Total } & 27 & 20.45 & 32 & 24.24 & 44 & 33.33 & 29 & 21.97 & 132 & 100 \\
\hline
\end{tabular}

Table (4) Incidence of $G$-ve bacterial species from examined tissues and organs of marine fish.

\begin{tabular}{|l|c|c|c|c|c|c|c|c|c|c|c|c|}
\hline Organ & \multicolumn{2}{|c|}{ A. hydrophila } & \multicolumn{2}{|c|}{$\begin{array}{c}\text { Ps. } \\
\text { fluorescens }\end{array}$} & \multicolumn{2}{|c|}{$\begin{array}{c}\text { Ps. } \\
\text { aeruginosa }\end{array}$} & \multicolumn{2}{|c|}{$\begin{array}{c}\text { V. } \\
\text { alginolyticus. }\end{array}$} & \multicolumn{2}{|c|}{ V. Cholerae. } & \multicolumn{2}{c|}{ Total } \\
\hline & No. & $\%$ & No. & $\%$ & No. & $\%$ & No. & $\%$ & No & $\%$ & No. & $\%$ \\
\hline Liver & 23 & 44.23 & 6 & 25 & 3 & 37.5 & 14 & 36.84 & 2 & 20 & 48 & 36.36 \\
\hline Kidney & 19 & 36.54 & 12 & 50 & 3 & 37.5 & 12 & 31.58 & 4 & 40 & 50 & 37.84 \\
\hline Spleen & 6 & 11.54 & 2 & 8.33 & 1 & 12.5 & 9 & 23.68 & 3 & 30 & 21 & 15.91 \\
\hline Gills & 4 & 7.69 & 4 & 16.67 & 1 & 12.5 & 3 & 7.89 & 1 & 10 & 13 & 9.85 \\
\hline Total & 52 & 39.39 & 24 & 18.18 & 8 & 6.06 & 38 & 28.79 & 10 & 7.58 & 132 & 100 \\
\hline
\end{tabular}


Table (5) Mortality rate of experimentally infected fish with A. hydrophila, Ps.fluorescens, Ps.aeruginosa, V.alginolyticus and V. cholerae.

\begin{tabular}{|c|c|c|c|c|c|c|c|c|c|c|c|}
\hline \multirow[t]{2}{*}{ Group. } & \multirow[t]{2}{*}{ Dose per fish. } & \multirow[t]{2}{*}{$\begin{array}{l}\text { Fish } \\
\text { No. }\end{array}$} & \multicolumn{7}{|c|}{$\begin{array}{l}\text { Dead fish during } 7 \text { days } \\
\text { after } \\
\text { Injection of pathogenic } \\
\text { bacteria. }\end{array}$} & \multirow{2}{*}{$\begin{array}{l}\text { No. } \\
\text { of } \\
\text { dead } \\
\text { fish. }\end{array}$} & \multirow[t]{2}{*}{ MR\% } \\
\hline & & & 1 & 2 & 3 & 4 & 5 & 6 & 7 & & \\
\hline 1 & $\begin{array}{c}\text { A.hydrophila } \\
0.2 \mathrm{ml} \text { of } 3 \times 10^{7} \mathrm{CFU}\end{array}$ & 10 & 3 & 3 & 3 & 1 & - & - & - & 10 & $100 \%$ \\
\hline 2 & $\begin{array}{c}\text { Ps.fluorescens } \\
0.2 \mathrm{ml} \text { of } 3 \times 10^{7} \mathrm{CFU} \\
\end{array}$ & 10 & 2 & 2 & 1 & 2 & 1 & - & - & 8 & $80 \%$ \\
\hline 3 & $\begin{array}{c}\text { Ps.aeruginosa } \\
0.2 \mathrm{ml} \text { of } 3 \times 10^{7} \mathrm{CFU}\end{array}$ & 10 & $\mathbf{0}$ & 2 & 2 & 2 & - & - & - & 6 & $60 \%$ \\
\hline 4 & $\begin{array}{c}\text { V.alginolyticus } \\
0.2 \mathrm{ml} \text { of } 3 \times 10^{7} \mathrm{CFU}\end{array}$ & 10 & 2 & 3 & 3 & 1 & - & - & - & 9 & $90 \%$ \\
\hline 5 & $\begin{array}{c}\text { V. cholerae } \\
0.2 \mathrm{ml} \text { of } 3 \times 10^{7} \mathrm{CFU}\end{array}$ & 10 & - & - & - & - & - & - & - & - & $0 \%$ \\
\hline 6 & $\begin{array}{c}\text { V. cholerae } \\
0.2 \mathrm{ml} \text { of } 2.5 \times 10^{8} \mathrm{CFU}\end{array}$ & 10 & - & - & - & - & - & - & - & - & 0\% \\
\hline 7 & $\begin{array}{c}\text { Control group } 0.2 \mathrm{ml} \text { of } \\
\text { sterile saline }\end{array}$ & 10 & - & - & - & - & - & - & - & - & $0 \%$ \\
\hline
\end{tabular}

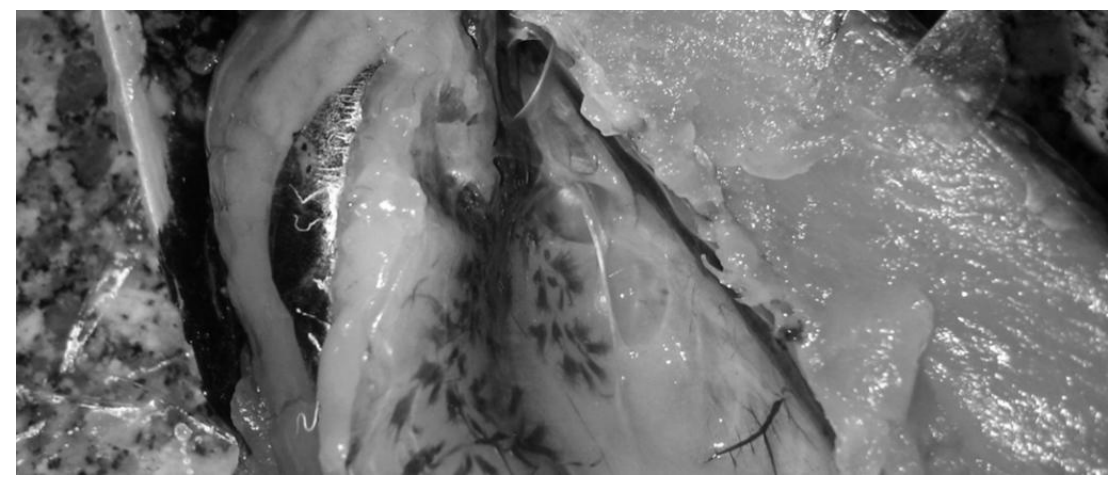

Photo (1) Diseased M. capito showed hemorrhages in peritoneum.

\section{Discussion}

Fish are susceptible to a wide variety of bacterial pathogens.
Naturally infected marine fish (M.capito \& T.zilii) were clinically examined and found darkness of external body surface, opacity of 
eye, exophthalmia and some fish showed hemorrhages in eye, scales detachment and large irregular hemorrhagic areas into many parts of the body, at base of fins, anal fin and coudal peduncle. This results supported with that mentioned by Toranzo et al (2005), El-Ashram and Azza(2006), and Moustafa et al (2010). Post mortem finding of most examined fish pointed out that liver appeared to be pale anemic, friable with some hemorrhagic patches on its surface and in some cases appear congested. Kidney and spleen were congested and slightly enlarged, and in some cases pale. In some fish appeared hemorrhagic areas in the abdominal wall .This results are in accordance with those reported by Toranzo et al (2005),El- Ashram and Azza (2006), Moustafa et al (2010) and El-Refaey (2013).

In this work many types of bacterial strains were isolated from marine fish including A. hydrophila, Ps.fluorescens, Ps.aeruginosa, V.alginolyticus and $V$. cholerae. And this results agree with Kannapiran et al (2009) who declared that Vibriosis was one of the most prevalent fish diseases caused by bacteria belonging to the genus Vibrio. V.alginolyticus, V.cholerae (non-O1), V. vulnificus (Biotype 2), V. anguillarum, were considered to be predominant fish pathogens. Similar to Hossain et al (2011) who suggested that Aeromonas and Pseudomonas were the important bacterial pathogens frequently isolated from the diseased fish throughout the world. Regarding prevalence of bacterial isolates in this work, the high prevalence of bacterial isolates was recorded to A. hydrophila (39.39\%), followed by V.alginolyticus (28.79\%),Ps. fluorescens (18.18\%). And this results in accordance with Zorrilla et al (2003) who showed that the most frequently isolated microorganisms were identified as Vibrio (69.90\%). Other microorganisms belonging to Pseudomonas spp., and Aeromonas spp., in which V.alginolyticus was the most frequently species isolated (21.35\%), and with Ullmann et al (2005) who demonstrated that a total of 134 Aeromonas strains were classified as A. hydrophila (67\%), A.caviae $(26.1 \%)$, and A.sobria (6.0\%) by biotyping. Also Ahmed (2004) who isolated ps. fluorescens from naturally infected Mugil species with percentage $21.33 \%$.

In regards to the seasonal prevalence of $A$. hydrophila the result pointed out that the highest prevalence of $A$. hydrophila was recorded in winter (51.85\%), followed by summer season (40.91\%),then spring (37.5\%), while the lowest recorded in autumn $(27.59 \%)$.Several

researchers investigated that motile aeromonas spp. These results are in concordance with Hayes (2000) who concluded that outbreaks of $A$. hydrophila were usually associated with change in environmental conditions. Stressors including 
overcrowding, high temperature, sudden change in temperature, poor nutritional state, and fungal or parasitic infection that made stress on fish and increase its susceptibility to the infection. On the other hand Maalej et al (2003) noticed that Aeromonas dynamics exhibited a seasonal prevalence in natural seawater, Aeromonads decreased very rapidly in sea water during the cold period from the end November to April.

In regards to the seasonal prevalence of Ps.fluorescens our results detected that the highest prevalence of Ps.fluorescens was recorded in winter $(29.63 \%)$, then autumn $(27.59 \%)$ and spring (25\%). While not recorded in summer season. This reveals that Ps.fluorescens has certain affinity to low temperature for propagation and spreading infection. These results are supported by Hoshino et al (1997) who illustrated that the proteinase activity of Pseudomonas spp. increase in low temperature. And Iqbal et al (1999) and Golomazou et al (2006) who demonstrated that Pseudomonas were isolated mainly in cold months of winter .while these results disagree with Hoda et al (1999) who revealed that the prevalence of Pseudomonas were lower in winter than summer. On contrast this result was not in accordance with Eissa et al (2010) who isolate Pseudomonas spp. from and revealed significant difference among four seasons, it was $43.33 \%$ (April 2008), $24.44 \%$
(August 2008), 21.11\% (November 2008) and $17.77 \%$ (January 2009). And mentioned that the high prevalence of Ps.fluorescens in winter season may due to the high affinity of this bacteria to low water temperature as concluded by $\boldsymbol{E l}$ Moghazy (2004).

In regards to the seasonal prevalence of Ps.aeruginosa thes results showed that the highest prevalence of Ps.aeruginosa was recorded in spring (12.5\%), followed by summer $(9.09 \%)$. But not recorded in winter and autumn. This result agree with Eissa et al (2010) who isolated Ps.aeruginosa 12 isolates of total 80 Pseudomonas spp. isolates $(15 \%)$ from marine fish.

In regards to the seasonal prevalence of V.alginolyticus the results were demonstrated that the highest prevalence of V.alginolyticus was recorded in summer (36.36\%), then autumn $(34.48 \%)$, followed by spring $(21.88 \%)$, while minimal recorded in winter $(18.52 \%)$.The obtained results of seasonal prevalence of V.alginolyticus were higher than that reported by Mustafa et al (2010) who mentioned that the highest prevalence of V.alginolyticus in summer $(8.57 \%)$, autumn $(5.30 \%)$, spring $(2.04 \%)$ and $(0.81 \%)$ in winter .On the other hand, Golomazou et al (2006) reported that V.alginolyticus were not associated with a particular season. 
Concerning to rate of recovery of bacterial isolates in various organs our investigation demonstrated that, prevalence of total bacterial isolates was $(37.84 \%)$ in kidney so it is the most predominant site for isolation of bacterial pathogens that causing septicemia as it is considered as one of the main hematobiotic organs of fish. Followed by liver (36.36\%), then spleen $(15.91 \%)$ and finally gills $(9.85 \%)$. And this result nearly agree with El-Refaey (2013) who concluded that most of bacterial infections affect haemobiotic system mainly liver, kidney and spleen.

From the results of antibiogram sensitivity test, it cleared that ciprofloxacin and naladixic acid were more effective against A.hydrophila, and this results agree with El Ashram and Azza (2006), Abou El Atta and El Tantawy (2008) and Enany et al (2011). While ciprofloxacin and rifampicine more effective against Pseudomonas spp. and these results similar to that detected by Akinbowale et al (2007) and Enany et al (2011). While V.alginolyticuswas highly sensitive to ciprofloxacin, and this results supported with that obtained by Wafeek et al (2007) and Enany et al (2011).

It was concluded that the highest prevalence of bacterial isolates causing infection in marine fish were by A.hydrophila followed by V.alginolyticus, then Ps. fluorescens and the minimal prevalence was recorded for Ps.aeruginosa and $V$. cholerae. And the higher rate of infection recorded in summer season followed by the spring then autumn, in contrast the minimal incidence of infection were recorded in winter. Ciprofloxacin was considered the drug of choice for treatment and prevention of bacterial infection in marine fish either alone or combined with other antibiotics.

\section{References:}

Abou El Atta, M. E. and El Tantawy, M. M. (2008): Bacterial causes of skin ulcers affection in Tilapia niloticus with special reference to its control. The eighth international symposium in Tilapia in aquaculture, $\operatorname{Vol}(2), 1419-1434$.

Ahmed, E. Z. A. (2004): Studies on disease problems in Mullet species in Dakhlia province. A thesis for degree of M. V. Sc fish diseases and manage-ment Dep. Faculty of Vet. Med. Man-soura University.

Akinbowale, O. L.; Peng, H. H. and Barton, M. D. (2007) :Antibiotic and heavy metal resistance in motile Aeromonas and Psudomonas from rainbow trout (Oncorhynchusmykiss) farms in Australia . Inter. J. Antimicrobial. Agents, 30(2):177.

Austin, B. and Austin, D. A. (2007): Bacterial Fish Pathogens. Diseases of Farmed and Wild Fish. Springer-Praxis Publishing, Ltd., United Kingdom. 
Austin, B. \& Austin, D. A. (1999): Bacterial fish pathogens; Disaese of farmed and wild fish. $3^{\text {rd }}$ ED. pulblished in association with praxis publishing Chichester.

Bergey's Manual ${ }^{\circledR}$ of Systematic Bacteriology (2005): Springer

Buller, N. B. (2004): Bacteria from Fish and other Aquatic Animals: A Practical Identification Manual. $\mathrm{CAB}$ International publishing, Cambridge, Oxford shire, UK, $361 \mathrm{pp}$.

Eissa, I. A. M.;Abo El Ghiet, E. N;shaheen, A. A and Abbass, A. (2010):Characterization

Pseudomonas Species Isolated from Tilapia"Oreochromis niloticus" in Qaroun and Wadi-El-Rayan Lakes, Egypt , Global Veterinaria , 5 (2): 116-121.

El-Ashram, A. M. M. and Azza, M. M. (2006):Acontribution on bacterial pathogins infecting mullet( Mugilcapito) cultured in fresh water farms in Sharkia governorate. "Egypt. J. Agric. Res., 84(1B).

El-Moghazy, D. F. (2004): Studies on pseudomonas septicemia in cultured Oreochromisniloticus fish. M. V. Sc., Thesis, Fish Disease and Management, Fac. Vet. Med. Suez Canal Univ.

El-Refaey, A. M. E. (2013):Studies on major bacterial diseases affecting fish ; Tilapia Oreochromisniloticus, Catfish, Clariasgariepinusand mullets in Port Said, Egypt with special references to its pathological alterations, science journal:5(2):514
Enany, M. EL.; Ibrahim H. M.; Abou El Atta, M. El.;ElAdawy, M. M. (2011):Bacteriological and histopathological studies on some bacterial pathogens causing diseases in cultured mugil capito fish in Ismailia governorate. SCVMJ, XVI (1).

Golomazou, E.; Athanassopoulou, F.; Vagianou, S.; Sabatakou, O.; Tsantilas, H.;Rigos, G. and Kokkokiris, L. (2006): Disease of white sea bream (Diplodussargus L. ) reared in experimental and commercial conditions in Greece Turky. J. Vet. Anim. Sci;30:389396.

Hayes, J. (2000): Disease of fish spring 2000 Term project Oregon State University. MB52.

Hoda, H.; jussef, H.; Abd el kader, M. and Abd-allatef, H. H. (1999): Quantitative and qualitative studies on bacterial microflora of fish reared in fresh water in Alexandrie. J. Egyption, 34:315330.

Hoshino, T.; Ishizaki, K.; Sakamoto, T. \&Kumeta, H. (1997): Isolation of a Pseudomonas species from fish intestine that produces aprotease active at low temprature. Appl. Microbiol., 25:70-72.

Hossain, M. M.; Rahman, M. A.; Mondal, A. S.; and Chowdhury, M. R. p. (2011): Isolation of some emergent bacterial pathogens recovered from captured and cultured fisheries in Bangladesh, 
Bangld. Res. publ, Journal:6(1):7790.

Iqbal, M. M,; Chowdhury, M. B.; Islam, M. A.; Baqui, M.; Karim, S. M.; Tajimia, K. and Ezura, Y. (1999): Seasonal fluctuations of motile areomonads and pseudomonads in cultured pond of migralcirrhinus in bengladesh. Asean fish, Sci., 12:17-24.

Kannapiran, E.; Ravindran, J.; handrasekar, R. and Kalaiarasi, A. (2009): Studies on luminous, Vibrio harveyi associated with shrimp culture system rearing Penaeusmonodon. J. Environ. Biol., 30, 791-795.

Maalej, S.;Mahjoibi, A.; Alazri, C. and Dukan. (2003): Simultaneous effects of environmental factors on motile Aeromonas dynamics in urban effluent and in the natural sea water,Water Res., 37:2865-2874.

Moustafa ,M.; Laila , A. M; mahmoud, M. A ;soliman, W. S, and EL-gendy , M. Y. (2010): Bacterial infections affecting marine fishes in Egypt, Journal of American Science :6(12):13141324.

Schaperclaus, W; Kulow, H. and Schreckenbech, K. (1992): Fish diseases Vol. 1. AA. Balkema/rotterde.
Toranzo, A. E., Magaríos, B. \&Romalde, J. L. (2005): A review of the main bacterial fish diseases in mariculture systems. Aquaculture 246: 37-61.

Ullmann, D.;Krause, G.;Knabner, D.; Weber, H. and Beutin, L. (2005):Isolation and characterization of potentially Human pathogenic, Cytotoxin producing Aeromonas Strains from Retailed seafood in Berlin, Germany, J. Vet. Med., 52:82-87.

Wafeek, M.; Abou El Atta, M. and Ebrahem, G. (2007): Heavy metals and bacterial distribution in different organs of Grey mullet (Mugilcephalus) cultured in different environmental conditions. Egypt J. Aquat. Biolo\&Fish, Vol. 11, No3; 1125-1144.

Zorrilla, I.; Chabrillo'n, M.; Arijo, S.; Dı'az-Rosales, P.;Martı'nez-Manzanares, E.; Balebona, M. C. and Morin igo, M. A. (2003): Bacteria recovered from diseased cultured gilthead sea bream (Sparusaurata L. ) in southwestern Spain. Aquaculture $218: 11-20$. 


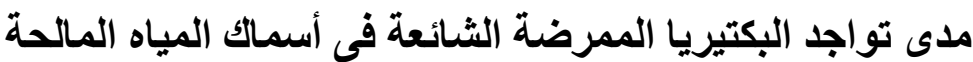

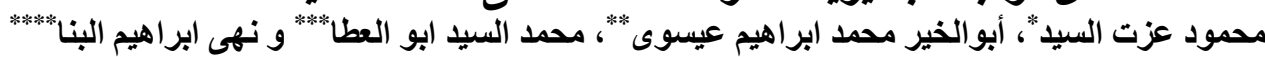

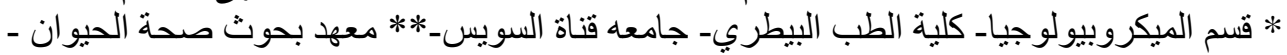

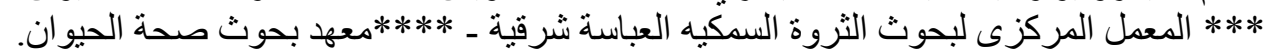

تم اجر اء هذه الدر اسة على عدد . . . سمكه من أسمالك المياة المالحه ممثلك في (أسماك الطوباره و

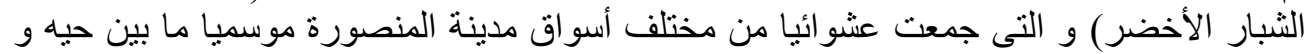

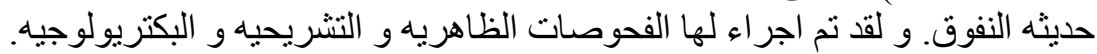

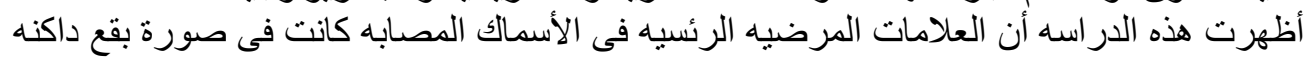

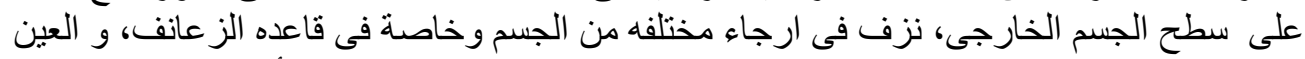

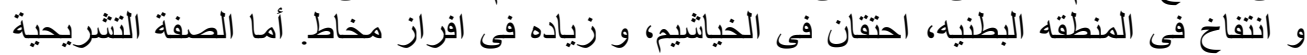

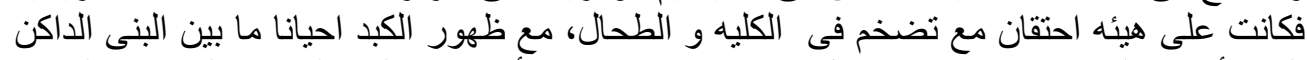

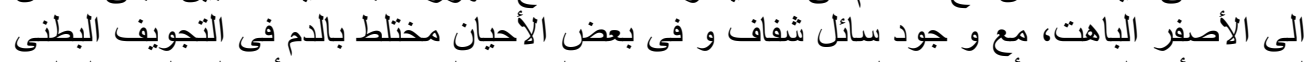

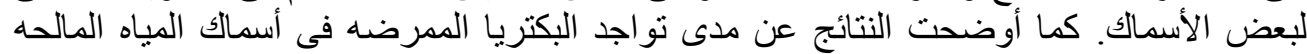

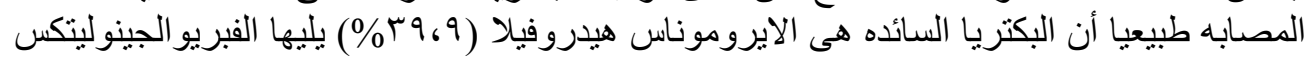

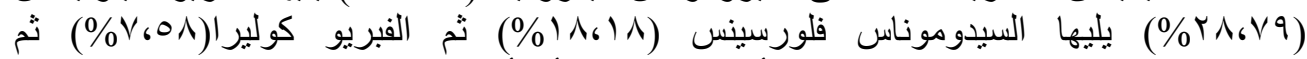

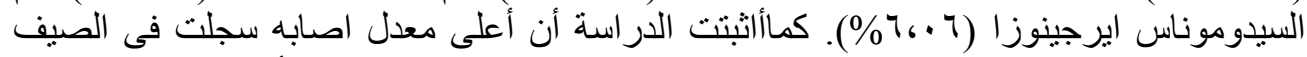

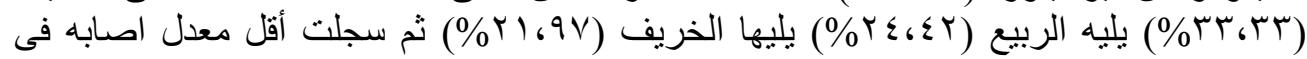

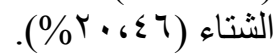

أوضحت العدوى الصناعية أن الايروموناس هيدروفيلا أكثر البكتريا المعزوله ضر اوه حيث سببت هوبت هيث

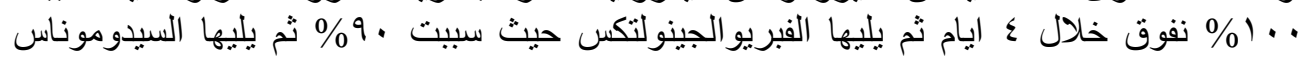

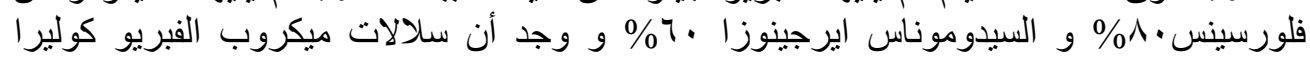

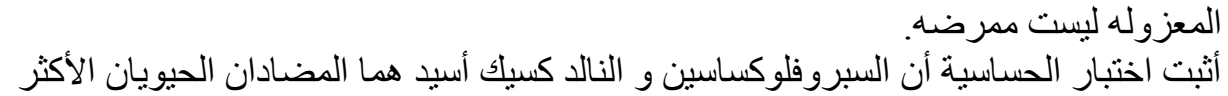

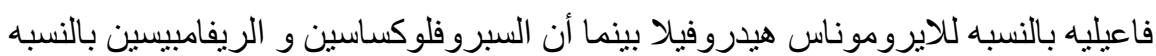

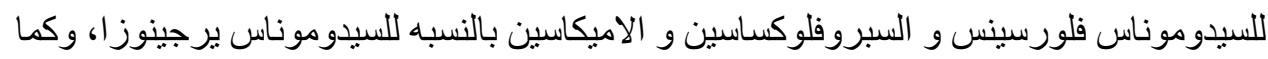

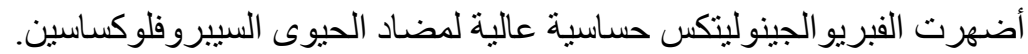

